\title{
RIGLYNE VIR DIE ONDERWYS.
}

In die afgelope vyftig jaar sedert die Unie tot stand gekom het, is veel op die gebied van onderwys tot stand gebring. Dit is heel natuurlik dat 'n mens sou vra: Wat van die toekoms?

Van die onderwys, met name die onderwysers/esse, word verwag om 'n volk liggaamlik en geestelik te bou en sorg te dra dat sy kinders veral deur 'n gesamentlik trou tot 'n hegte eenheid verbonde raak. In sy wese is dit 'n groeiproses van onvolwassenheid tot volwassenheid. Sodra laasgenoemde bereik word, word van die volwassenes verwag om die kultuur verder te dra en aan die nuwe geslag te oorhandig - 'n nimmer eindigende proses in hierdie bedeling. Die kultuur moet ten eerste die eie wees totdat dit heg gefundeer is, waarna kennis van alle ander verwante kulture voordelig aangebring kan word. Onderwys wat nie daarin kan slaag om nasionalisme in die breedste en suiwerste betekenis van die woord op te wek nie, moet noodwendig huigelary wees. Hierdie Afrikaanse nasionalisme soos deur die Voortrekkers gedra is, moet hom van andersoortige nasionalismes onderskei en veral daarin onderskei dat die blanke 'n veeleisende taak in Suid-Afrika het, nl. om selfs die massas ongeletterdes in sy midde te kersten volgens dic voorskrifte van Gods Woord, al haal hy hom in sy pogings tot vrywording van homself en van die massas die kritiek van die hele wêreld op die hals. Hierdie kritiek en vyandigheid verval en word verpletter teen dic rots van Christelike geloof waarop die handelwyse van die blanke gevestig is.

Afrikaanse nasionalisme is die riglyn vir die toekoms: daadwerklike getrouheid aan die tradisies van die volk, al bestaan dit uit verskillende elemente: Afrikaans-, Engels-, Hollands-, Duitsen ander sprekendes wat hulle op 'n Westerse beskawing kan beroem. Die onderwys moet in die volgende jare die gemeenskaplike trou aan 'n eie vaderland, sonder enige inmenging van buite, op die harte van die volk se kinders ingraveer, sodat hulle met die grootste afkeuring sal neerkyk op die vreemdeling wat dit sal durf waag om verdeeldheid te saai. Wanneer die andertaliges wat hierheen verhuis die onderverdeelde trou aan mekaar en aan die land $c:$ sy regering skenk, dan sal bulle die voorbeeld van die getroues onmiddellik navolg. Daarmee hang saam die liefde vir die eie taal en die eerbied en respek vir die ander taal as gelykwaardig daarmee. Dit is absoluut noodsaaklik dat die onderwys geskille oor taalprobleme sal kan bylê.

In die bepaling van riglyne is dit noodsaaklik om die daarstelling van in Nasionale Onderwysraad onder oë te sien. Ons weet dat politici wat ongeIukkig nie opvoedkundig en filosofie-opvoedkundig geskoold is nic, hulle met die saak bemoei en 'n oordeel wil uitspreek as sou sekere regte van die provinsies hulle ontneem word en diversiteit wat alle onderwysstelsels moet kenmerk, daarmee heen is. Dit is eintlik 
ironies, indien nie tragies nie, dat die onderwysstelsel van 'n volk en veral van 'n worstelende jong volkie soos die Afrikaners, 'n bron van krakeel en verdeling is. Dit was die volk inherent moet saambind op die weg van nasieskap, nl. sy onderwysstelsel, word 'n instrument in die hand van onoordeelkundige politici om onrus in die gemoedere van die volk te saai. Indien hulle daarin slaag, sal dit beteken dat die weg van verdeeldheid op hierdie gebied sedert die Unifikasie van die provinsies in 1910 nog steeds sal voortduur. En dit het reeds gans te lank geduur.

In plaas van eenheid op onderwysgebied het verdeelde beheer ingetree. Omdat daar geen helderheid omtrent beleidsake was nie, het provinsialisme, hoewel dit weggeredeneer word, nadelig en diep in die volksiel wortel geskiet. Geen wonder dat die volk herhaalde male moet opgeroep word om tot 'n eenheidstrewe te kom tydens groot volksfeeste omdat sy onderwys, tot skaamte van ons almal, nie daartoe in staat was nie. Omdat die krag van 'n volk dikwels verflou en deur die afwesigheid van 'n nasionale onderwysstelsel nie stuwend gehou wcrd nie, moet dit deur grootskeepse herdenkingsfeeste aangevuur word. En nou is dit duidelik dat die hele volk, sowel Afrikaans- as Engelssprekendes, nie deur hierdie byeenkomstes in mekaar se arms geja word nie.

Ten einde die groot mate van verdeeldheid in die geledere van die Suid-Afrikaanse volk te bekamp, is ' $n$ nasionale beleid ten eerste ' $n$ sine qua non. In die 1910 ZUID-AFRIKA WET (artikel 85 - iii) is verdeelde beheer geskep, aangesien die vier Provinsiale Rade elkeen vir die beheer van dic onderwys binne sy grense verantwoordelik gehou is, uitgesonderd natuurlik hoër onderwys wat die taak van die Unie-Parlement was en natuurlik nog is. Omdat niks insake beleid gerep is nie, het elke Provinsie sy eie beleid begin bepaal nadat sy eie provinsiale onderwysdepartement in die lewe geroep is.

Die Wet het voorsiening gemaak dat die toedrag van sake wat geskep is, slegs vir vyf jaar sou voortduur waarna, by implikasie, 'n nasionale onderwysstelsel die lig sou sien. Daardie vyf jaar het reeds tientalle jare geword. Die spore van verdeeldheid, omdat die eenheidsgedagte ontbreek het, het dieper geraak. Dit is vandag so diep dat dit baie seer maak. Hierdie innerlike verdeeldheid en verwarring moet drasties beëindig word as ons hier 'n eenheid teenoor die wêreld wil toon. En daardie cenheid, soos telkemale in lirisistye in oorsese lande in die verlede getoon is, moet deur 'n onderwysstelsel wat in sy wese nasionaal is, bewerkstellig word. Soos sake nou staan, beloer die provinsies mekaar, omdat die een oor baie meer middele as die ander een beskik om die onderwys binne sy eie grense so doeltreffend en aantreklik moontlik te maak. Die vraag ontstaan dadelik waarom die kinders van die volk in bv. een van sy provinsies oor beter onderwysfasiliteite as in ' $n$ ander provinsie beskik. So word 'n nasie nie gebou nie!

Vir die Suid-Afrikaanse volk is 'n nasionale onderwysstelsel die waarborg vir sy voortbestaan. Met so 'n stelsel word beoog dat die hele gebied van onderwys, in al sy fasette: voorskoolse, 
laer, middelbare, hoëre, tegniese, beroeps-, liggaarnlike en alle ander vorme van onderwys (bv. korrespondensiekursusse), ook naskoolse (bv. volwassenes) oorsien, beplan en georganiseer moet word in die lig van 'n nasionale beleid, as gevolg waarvan nie alleen die geheel nie maar ook die verskillende samestellende dele bevoordeel word, sonder die gevaar van strakheid en onbuigbaarheid wat altyd as goggas voorgehou word. Die instelling van 'n Nasionale Onderwysraad, bestaande uit verteenwoordigers van al die provinsies se onderwysdepartemente en van die Departement van Onderwys, Kuns en Wetenskap, sal dien as eerste stap in die verwesenliking van volkseenheid en volkstrou.

Eienaardig genoeg dat juis genl. Smuts (die Smutswet van 1907) voorsiening gemaak het vir 'n nasionale onderwysraad, wat na ag-en-vyftig sittings en belangrike beraadslagings oor so 'n stelsel, deur die Uitvoerende Komitees van die provinsies vervang is. Laat ons dit ruiterlik erken dat ons volk in sy eenheidsgedagte veragter het as gevolg van daardie vervangingsdaad. Ons is nou vinnig besig om die pad wat byster geraak is, te vind. Hoe gouer ons tot 'n verklaarde nasionale beleid kan kom, hoe beter. So 'n beleid sal noodwendig volg nadat die Raad sy aanbevelings oor die hele aangeleentheid aan die Minister van Onderwys voorgelê het. Vir elkeen wat weet watter studieveld onderwys oorspan, is dit duidelik dat so ' $n$ Raad in 'n permanente hoedanigheid sal moet funksioneer, omdat die doelstellings van onderwys, nl. die sosiale, ekonomiese, politieke en kulturele inbedding in die maatskappy, dit sal verg. Die Raad sal die Minister van Onderwys moet help om sy vinger op die pols van die snel veranderende maatskappy te kan hou en te sorg dat die onderwys hom daarby aan- en inpas. Hierdie Raad sal hom ook vergelykend moet vergewis van wat presies oorsee op alle onderwysgebiede plaasvind. Die onderwys, met name al sy tipes skole, opleidingskolleges en universiteite, moet aldus 'n lewende verband hou met die maatskappy en die volk waarvoor dit bedoel is.

Ons staan aan die vooraand van twee groot volksverhuisings: aan die een kant die verwydering van die surplus Bantoes in die blanke gebied, m.a.w. 'n verskerpte toepassing van aparte ontwikkeling van blank en nie-blank; aan die ander kant 'n grootskeepse immigrasie veral omdat die „winde van verandering" oor Suid-Afrika onder 'n nuwe staatsvorm, nl. die Republiek, acnstaande is. Die Republiek moet bewerkstellig wat die monargie nie kon bereik nie, nl. groter politieke eenheid. In die volgende paar jare sal die wêreld in sy kritiek uitgewoed wees, omdat kritiek in die vorm waarin dit hom nou openbaar en veral waar dit op onware en skewe voorstellings gegrond is, moet uitsterf: die waarheid sal seëvier. Suid-Afrika se binnelandse veiligheid, rassevrede, ekonomiese opbloei en stabiliteit sal duisende immigrante lok, indien nie miljoene nie.

Hierdie twee verhuisinge bring die volgende mee: die blanke pas hom vinniger by die arbeidsbeginsel in sy eie huis, tuin en landerye aan. Van elke man en vrou en seun en dogter word veel meer as in die verlede verwag. 
Hierdie heropvoeding tot arbeid word met welslae bekroon, omdat dit die siel adel. Die instromende immigrante wat met selfarbeid groot geword het, stel hierin 'n kragtige voorbeeld en die proses tot onafhanklikheid word verhaas. Daarmee ook die proses tot selfverwesenliking. Hierdie nuwe gesindheid teenoor wat vroeër naturellearbeid was, kan die volk as 'n geheel slegs ten goede kom. Dit is bindend en behoudend.

Dit bring ons by die nasionalisering van die voorskoolse, nl. kleuteronderwys, wat tot dusver aan private inisiatief oorgelaat is. Die werkende moeder wie se kragte gedeeltelik of in die geheel deur die nuwe omwenteling op arbeidsgebied deur die staat opgeëis word, het die reg om te verwag dat haar klein kindertjies wat nog nie skool gaan nie, goed versorg, reg opgevoed, word en selfs deeglike grondliggende onderrig ontvang waarop die skool later heg kan voortbou.

Dit voer ons verder: die verlenging van die skooldag as 'n voldonge feit, van smôrens vroeg tot smiddae laat wanneer die ouers huiswaarts keer. Die skoolprogram sal nou die volgende insluit: die gewone skoolprogram soos dit tans bestaan, plus middagmaaltye, tuiswerkroosters, alle buiteskoolaktiwiteite wat selfs die leerlinge wat nie aan sport kan of mag deelneem nie, kan betrek. Vir sodanige leerlinge sal 'n interessante stokperdjieafdeling in die lewe geroep word waar die leerlinge liggaamlik en geestelik gesond en aktief besig gehou kan word. Daarmee sal die probleem van dwalende kinders wie se ouers uitwerk, die kop ingeslaan wees.
Die jeug sal terselfdertyd tot groter dissipline gebring word. Elke skool sal sy eie tuiswerkrooster moet afhandel en wel onder toesig en leiding van die onderwysers. Sodra dit gebeur, sal die onderwysers/esse tot 'n beter verhouding tussen skool- en tuiswerk geraak en meteens besef dat kinders wat met tuiswerk oorlaai word, soos dit deesdae veral in die hoër skole plaasvind, nie in daardie mate bevoordeel word soos wat teoreties gedink word nie. Oor die mate van gesinsverbrokkeling wat hierdie toedrag van sake sal meebring, word hier nie gespreek nie. Die staat het reeds klaar besef watter kinderverwaarlosing tans plaasvind waar moeders uitwerk. Hier is 'n metode om die kind onder die toesig van onderwysers/esse te beskerm en te bewaak. En dit is op sigself 'n lofwaardige poging van die staat om die kind te behou.

Dit is nodig dat onderwysers en voornemende onderwysers hiervan kennis sal neem. Ook hulle sal heropgevoed moet word om 'n groter deel van die taak van die huisgesin as wat tans bestaan, oor te neem.

As gevolg van hierdie ekstra las en verantwoordelikheid op die skouers van die onderwysers volg noodwendig 'n verhoogde vergoeding. Dit spruit voort uit die gewilligheid van die belastingbetaler om te vergoed vir dienste wat hy vroeër self moes behartig. Daarby gee hy ook gewilliglik sy bydrae vir die ekstra maaltyd vir sy kind(ers) en vir die bewaring, versorging en onderrig van sy voorskoolse kind(ers).

Wanneer die kinders 'n langer skooldag het, sal die geleentheid gebied word om audio-visuele hulpmiddels by die 
onderwys, veral die film, die strookfilm, skoolradio-uitsendings en televisie wat binne die volgende tien jaar 'n voldonge feit is, beter te kan benut. Die onderwyskolleges sal 'n spesiale studie van hierdie hulpmiddels moet maak en die nuwelinge oplei om hulle te gebruik vir die doel waarvoor hulle beskikbaar gestel word, nl. om onderdele van vakke grondiger te bestudeer. Omdat die afdeling audio-visuele hulpmiddels by die onderwys 'n spesiale woord verdien, kan hierop nie in hierdie artikel diep ingegaan word nie. Dit bly egter vas staan dat in die lande waar die onderwysers wel opgelei is om daarvan gebruik te maak, hulle hul taak nie makliker vind nie, maar heelwat moeiliker. Die moeilikheid bestaan in die opbreking van komplekse van wat gesien en gehoor is deur besprekings en skriftelike take. Waar grootskeeps van die film, skoolradio-uitsendings en televisie gebruik gemaak en doeltreffend aangewend word, is dit duidelik dat leerplanne vertikaal uitgewerk moet word in plaas van horisontaal soos die neiging deesdae is. Die meeste leerplanne bevat te veel en te weinig: te veel in die breë en te weinig in die diepte. Dit gee dikwels aanleiding tot oppervlakkigheid sonder aktivering van die denke.

Die moderne neiging in die onderwys is tegnologies van aard. Daar is 'n geskreeu om tegnici, 'n oorbeklemtoning daarvan, sodat die volgende vakke as hoofvakke aan die universiteit in die slag bly: Afrikaans, Engels, Duits, Latyn en selfs natuurwetenskappe. Die tale bly in die slag. Die tekort aan taalonderwysers/esse is bv. 'n saak wat besorgdheid baar. Die Transvaalse Onderwysdepartement het onlangs besluit om, afgesien van wat die universiteite doen, hulle eie taalonderwysers vir sekere klasse op te lei. Hierdie saak is ook alreeds in die Departement van Onderwys, Kuns en Wetenskap aanhangig gemaak.. Die Nasionale Onderwysraad sal hier in die bresse moet tree en streng waak teen die verwaarlosing van die studie van tale, veral omdat taal die sosiale verkeers- en denkmiddel in alle vakke is. As die peil van taalonderrig daal, moet die peil van alle vakke noodwendig daal. Die belangrikheid van taalstudie en letterkunde sal andermaal voorrang geniet onder 'n nasionale beplanning en beleidsverklaring insake onderwys. Om taalstudente te trek, sal hulle opleiding of gratis moet geskied of hulle sal as onderwysers heelwat meer as ander onderwysers moet ontvang. Die taal is fundamenteel. Daarby sal die vereistes vir hoërtaalonderwysers meteens veel hoër gestel word; ten minste 'n meestersgraad, verkiesliker 'n doktorsgraad, sodat hulle betiteling die van professor kan wees, soos die hoërskoolonderwysers in België genoem word. Waarom nie? Dit sal die status van die onderwyser in ere herstel en die beroep in aansien by die volk bring. As dit eers in die tale plaasvind sal die ander vakke op die voet volg. Voordat hierdie hoër vereistes vir die hoërskoolonderwysers reggestel word, sal die professie nie kan bloei nie. Hierdie hoër kwalifikasies word nie ten opsigte van die laerskoolonderwysers gevra nie, aangesien hulle met volksonderwys te doen het, waarin die karakterontwikkeling, nie so seer kennis nie, op die spel is. 
In die naaste toekoms sal al meer en meer klem gelê word op die onderrig van Godsdiens en die Bybel, afgesien van al die menigerlei besware wat mense deesdae daarteen uit. In die cnderwys sal die manne en vroue al meer en meer na Gods wil moet leer vra en of, volgens Handelinge 5 vers 38 en $39, \ldots$ „hierdie voorneme of hierdie werk uit die mense is" . . . As dit so is ,sal dit vernietig word"; ,maar as dit uit God is, kan julle dit nie vernietig nie, dat dit nie miskien gevind word dat julle selfs teen God stry nie".

Terwyl ons met leerplanne besig en veral die tale en Godsdiens, mag ons die groot aantal instromende immigrante met hulle taaleie nie uit die oog verloor nie. Die toekomstige onderwysbeeld sal met meer tale op skool rekening moet hou en daarvoor voorsiening maak. Die gemiddelde Suid-Afrikaanse leerling en student is arm aan talekennis. Tale open die kulture van ander volke en dra by tot die geestelike vorming van die mens. Omdat ons in die toekoms meer rekening met ons Bantoe-buurstate sal moet hou as in die verlede, sal ons leerlinge op skool ook Bantoetale moet begin studeer. As meer Suid-Afrikaners in die verlede Bantoetale kon bestudeer het, sou ons onder die Bantoes baie meer volgelinge vir die Blanke se gedagtegang i.v.m. hulle toekoms gehad het. Onder 'n nasionale beleid sal sorg gedra word dat rasseverhoudinge deur middel van die talekennis onmiddellik verbeter sal word.

Daar is nog talle ander gedagtes oor riglyne wat nie almal genoem kan word nie. Die saak van ' $n$ maandelikse of halfmaandelikse onderwysbulletin, uitgegee deur die Departement van Onderwys, Kuns en Wetenskap as 'n staatsdepartement wat uiteindelik onafhanklik van die politiek staan en die koers van die geestelike en liggaamlike ontwikkeling van die volk bepaal, is ' $n$ saak waaraan in die komende jare veel aandag gewy sal word. Onderwysers wil graag ingelig word omtrent alle ontwikkelinge op die gebied van onderwys oor die hele wêreld. Dit sal een van die take van die Nasionale Onderwysraad wees om vir hierdie bulletin te sorg en toe te sien dat die verspreiding van kennis op hierdie vlak onverbeterlik is. Dit sal die Suid-Afrikaanse onderwysers onmiddellik op die wêreldkaart plaas en meebring dat hulle in die onderwysersuitruilskemas tussen lande gesogte mense word.

Onder die Nasionale onderwysstelsel word dan beslis geskiedenis gemaak: 'n nuwe taak word gestel, die doelstellings van onderwys word by hernuwing uitgelewe en die mens word volmaaktelik vir elke goeie werk toegerus, omdat daar 'n harmoniese samewerking tussen hand, hart en hoof sal wees, en hy gevolglik sy koninklike, priesterlike en profetiese werk volgens opdrag van die Meester doeltreffend kan uitvoer.

\section{J. L. DU PLOOY.}

Pretoria. 